\title{
Novice Teachers' Experiences of Teaching Visually Impaired Learners in the Foundation Phase: A Case of Inclusive KwaNyuswa Rural Schools
}

\author{
Mncube D. W. ${ }^{1}$, Hadebe-Ndlovu B. ${ }^{2}$, Uleanya C. ${ }^{3, *}$ \\ ${ }^{1}$ Department of Social Sciences Education, University of Zululand; KwaDlangezwa, South Africa \\ ${ }^{2}$ Department of Early Childhood Education, University of the Free State, South Africa \\ ${ }^{3}$ Department of Business Management, University of South Africa, UNISA, Gauteng, South Africa
}

Received February 19, 2021; Revised March 22, 2021; Accepted May 11, 2021

\begin{abstract}
Cite This Paper in the following Citation Styles
(a): [1] Mncube D. W., Hadebe-Ndlovu B., Uleanya C. , "Novice Teachers' Experiences of Teaching Visually Impaired Learners in the Foundation Phase: A Case of Inclusive KwaNyuswa Rural Schools," Universal Journal of Educational Research, Vol. 9, No. 6, pp. 1179-1187, 2021. DOI: 10.13189/ujer.2021.090607.
\end{abstract}

(b): Mncube D. W., Hadebe-Ndlovu B., Uleanya C. (2021). Novice Teachers' Experiences of Teaching Visually Impaired Learners in the Foundation Phase: A Case of Inclusive KwaNyuswa Rural Schools. Universal Journal of Educational Research, 9(6), 1179-1187. DOI: 10.13189/ujer.2021.090607.

Copyright $\bigcirc 2021$ by authors, all rights reserved. Authors agree that this article remains permanently open access under the terms of the Creative Commons Attribution License 4.0 International License

\begin{abstract}
In the past, special education to serve this vulnerable group in public schools was completely neglected. Only well-resourced special schools were privileged to serve the minority in South Africa. The current education system prepares teachers who are generalists, with very little specialised training to teach visually impaired learners. Hence, this study presents a case study of six novice teachers employed without the proper qualification to teach visually impaired learners in the Foundation Phase. This study was premised on understanding that most Foundation Phase teachers have been teaching visually impaired learners without training. Qualitative method was adopted for data collection. This was done through the use of semi-structured interviews. Burden's theory on teacher development stages was used to analyse data. Findings reveal that novice teachers require immense support and guidance to teach visually impaired learners in the Foundation Phase. Otherwise, they are not providing the quality education envisaged in the Constitution of the Republic. The study therefore recommends amongst others that since government has responsibility to provide equitable and quality education to all people, irrespective of their physical condition, the quality of education provided for visually impaired learners in the Foundation Phase should be reconsidered. This is to ensure access with success, rather than
\end{abstract}

participatory access.

Keywords Foundation Phase, Novice Teachers, Teacher Education, Visually Impaired Learners

\section{Introduction}

Children with disabilities, like all others, have the right to a basic quality education as envisioned in Section 29 of the South African Constitution (RSA, 1997). This section guarantees to everyone the right to a fair, equal and just system of education free from unfair discrimination based on any form of disability Mwakyeja[1]. According to [2], visual impairment is just a condition, and all learners deserve no less than a quality education from highly qualified teachers to gain opportunities for lifelong learning, equal work opportunities, and participation in society. The level of frustration teachers and learners' has to endure causes anxiety and frustration [3]. Institutions of higher education in South Africa are complicit in violating the rights of these innocent learners as almost all B.Ed programmes that prepare teachers for mainstream curriculum fall short of this national imperative [4]. Coordination between both the DHET and the DBE is poor 
in addressing vulnerable minorities in our society by providing basic services guaranteed in the Constitution. The Curriculum Assessment Policy Statement (CAPS) outlines minimum measures required from professional teachers, such as basic content and pedagogical knowledge of teaching listening, speaking, reading and writing skills $[5,6,7]$. The study conducted by [4] reveals that although teachers possess technological knowledge, they tend to focus on Braille as a stand-alone skill, and inadvertently fail to integrate it with teaching. Fair enough, but being biased towards technological skills compromises the spirit of inclusive education principles [2,4]. In [8], efforts to build a learning environment that promotes full, personal, academic and professional development of all learners, irrespective of disability, are guaranteed. Ref. [8] derives its mandate from the [9] recommendations to all countries of the world to implement inclusive education as a cost-effective alternative to educating children with disabilities. Ref. [3] argues that despite this passionate plea, South Africa grapples with setting up fundamental basic structures and policy interventions in teacher training institutions to effect universal and inclusive education for learners with visual impairment. This study focuses on novice teachers who were trained to teach in general public schools, but were employed to teach learners with special needs such as those with visual impairment in the Foundation Phase (FP). The term "novice teachers" refers to teachers who have less than two years of teaching experience, or none at all [10]. The research objectives were to understand teachers' experiences and the coping strategies they are using to implement inclusive education in the CAPS curriculum. Ref. [11] argue that teachers with a general education training qualification struggle with visually impaired learners; they lack the appropriate knowledge to meet their needs. The novice teachers are not exposed to Braille.

\section{International Perspectives on Visual Impairment}

South Africa aspires to universal access to education by regarding inclusive education as one of the most significant resolutions of the Salamanca Conference held in 1994 [12]. The inclusive education agenda was a drive towards quality and equality in education for all, irrespective of disability [3]. It is against this backdrop that inclusive education was elevated in schools and universities to provide all learners with the opportunity of attending schools so that the "no children left behind" principle would be maintained [2]. The research strongly advises that their academic and social outcomes are better served when students are educated together $[13,14]$. As regards learners with visual impairment, teachers need to know how to contribute to establishing individual needs and strengths [3].

In many countries, such as Australia, Canada, Finland and the United States of America, learners with visual impairment attend mainstream schools $[15,16,17]$. In the US, learners with visual impairment have been included in the general education classroom since way before the 1975 official implementation of the so-called Education for All Handicapped Children Act (IDEA) [18,19]. The same scenario exists in the United Kingdom, where teachers are required to hold an initial teaching qualification plus the practical experience of teaching in the classroom for two years [14]. The study conducted by Ravenscroft[20] shows that over and above this, these teachers are expected to enroll for a postgraduate diploma from any recognised public university to acquire certification officially authorising them to teach visually impaired learners.

A study in Nepal by Lamichhane[21] reveals a positive correlation between teachers' years of teaching experience and experience of teaching learners with visual impairment. In Ghana, however, there was no correlation between teaching experience and teaching style adjustment [22]. It is therefore understandable that some teachers are hostile to inclusive education owing to poor resources to support schools. In instances where resources were provided, teachers were more likely to develop a positive attitude towards inclusive education [23].

\section{Teaching Learners with Visual Impairment}

There is no doubt that children with visual impairment are unique, and should be educated through a holistic team effort [24]. The study by the American Foundation for the Blind (AFB)[25], conducted in the United States, shows that these learners often learn through alternative mediums, using his/her other senses. Teachers of all ages should be capable of handling specialised instructions geared towards promoting learning for learners' unique abilities and learning needs [26]. One of the widely publicised injunctions in education states that to be successful in delivering curriculum, promoting learners' growth and prioritising the critical goals of the visually impaired, teachers must have a basic understanding of the unique learning needs of all learners, including those with disabilities [14, 15]. Within an inclusive environment, there is a high probability that teachers may encounter learners with a variety of visual impairments [27]. In such schools, teachers are generally nervous about their quality of training to cater for visually impaired learners owing to their one-sided academic training [14]. It is widely reported that only those educators who have received training in specialised education topics feel more comfortable about the notion of inclusion than those with limited training $[28,29]$. Studies indicate that the demand for specialised educational knowledge and training cannot be suppressed beyond this period owing to its positive impact on learners with visual impairment $[27,28,30]$. Learners with special needs learn best when teachers are competent and sensitive to their most basic educational needs, and then package instructions meticulously to meet them [30]. 


\section{Experience of Teachers}

The study conducted in Finland by [31] found that teachers always made assumptions about learners' needs rather than finding them out for themselves, or listening to what they say. In one of the case studies, a teacher would constantly tell her learners to speak up so that the whole class could hear [32]. After the publication of this study, Hopkins[33] issued a stern warning to teachers to be careful and make a concerted effort as it is easier to remove physical barriers than attitude barriers. Whilst this negligent attitude exists, some teachers are not willing to assist learners with visual impairment, at the worst of times not even allowing them to be recorded, nor reading what they write on the board [34]. This kind of experience cannot be allowed to continue unchecked when people are demanding equal and quality education for all [33].

Signs of encouragement came from Hopkins[33] study, when he demonstrated that acceptance and understanding of those with impairment grow with experience. A similar argument was made by Konur[35], that teachers are capable of learning to work with visually impaired students and improve their attitude over time. Ref. [36] took the argument a step further and found that visually impaired learners tend to rely on their senses of touch, hearing, smell, taste, movement and residual vision to gather information from their learning environments. A similar observation was made by [15], suggesting that teaching materials for students with visual impairment may not always be needed for classroom activities. Planning for the visually impaired starts with using proper lighting in order to be considerate to those learners with low vision or light sensitivity. Finally, once the classroom setting is established, teachers should ensure the setting is not changed. Ref. [36] point out that reorganisation of furniture tampers with learners' classroom orientation, movement, and location of desired spaces within the environment.

Additionally, this study investigated the experiences of teachers who teach visually impaired learners in the general education setting in six primary schools in KwaZulu-Natal. Most visually impaired learners are the most vulnerable group of learners, at the periphery of the mainstream education system in South Africa. While most countries treat this group with the utmost care and respect, tangible interventions at both policy and implementation levels are necessary. Internationally, visually impaired learners are best catered for by qualified teachers who have been subjected to strict specialised training. Previous studies have identified barriers to educating learners with visual impairment in mainstream education $[18,36,37,38]$. Some of the barriers were lack of specialised service, books, resources and technology to ensure equal access to specialised curricula. The policy and practice suggest that despite formalisation of inclusive education in public schools, the delivery of education to visually impaired learners remain questionable. This study zooms into teachers of visually impaired learners to explore their experiences as they implement curriculum, and interact with them daily. Thus, the reason for this study is to examine the perceptions and experiences of teachers of students with visual impairment in KwaNyuswa rural schools in KwaZulu-Natal Province, South Africa. The needs of the students with visual impairment deserve a high degree of skill, knowledge and empathy from frontline workers such as qualified teachers, support staff and SMTs.

\section{Method}

This research is underpinned by a qualitative case study of six novice teachers working in inclusive schools found in a rural area. Ref. $[39,40]$ assert that a qualitative case study allows the flexibility of collecting, analysing, and interpreting data, elaborating or refocusing research questions, and identifying and dealing with validity threats, all at the same time. All participants had less than five years of teaching experience in the profession. The research site was chosen based on availability and convenience from government sites catering for visually impaired learners. Qualitative method was employed for data collection; hence, semi-structured interviews were conducted for the six selected participants who comprised teachers of visually impaired learners, a head of centre, and one subject adviser responsible for ECD centres. The interview schedule was used to allow for uniformity in questions, however, follow-up questions were asked where necessary following the responses of participants in some instances since the interviews were semi-structured in nature. This gave room for further probing and insights, thus allowed participants to open up from the predetermined questions while talking about their experiences of teaching visually impaired learners.

\section{Sampling and Data Generation Methods}

This study used purposive sampling to identify and select participants. Ref. [41] defines purposive sampling as the "selection of participants based on some definite specific characteristics that qualify them to be holders of required data for the study Maree (2009:79)." Six FP teachers working with visually impaired learners participated in the data generation process. These participants were part of the group of master's students at UKZN (two were males and three were females). Due consideration to ethical standards took precedence over everything else to avoid conflict of interest that might jeopardise the good name of the two universities, and protect participants' autonomy and dignity [42]. These ethical considerations were applied along with the following main ethical principles: non-maleficence and beneficence [43]. In this regard, approval was sought from the Ethics Committee at the Faculties of Education, 
University of Zululand, and UKZN after intense scrutiny and deliberation.

Participation in this study was voluntary [44]. To assert their autonomy, participants signed a consent form [43]. To ensure their identity was concealed, pseudonyms were used. The Foundation Phase teachers were identified as Kate, Sthabana, Makuya, Landuwva, Takalani, and Pearl. Findings from narrative inquiry and semi-structured interviews were analysed and presented simultaneously using thematic analysis. The data analysis strategy most appropriate for the research questions was the identification of themes and patterns while collecting, transcribing, editing, and coding the field notes. Patience was required when watching for emerging codes and maintaining a constant comparative analysis of data collected while categorising and coding data for explanation and clarity [45]. In this regard, data analysis and interpretation involved triangulation to validate the information and draw conclusions. This is a small-scale case study and the results may not be generalised [46, 47].

\section{Findings and Discussions}

The main purpose of this study was to examine the perceptions and experiences of teachers of students with visual impairment. This section presents the results from participants. Findings from semi-structured interviews and the questionnaire were coded and analysed thematically. The findings are presented based on each of the identified themes.

\section{Theme 1: Teachers' professional training and skills to facilitate inclusive education}

The first theme that emerged during the data analysis was teachers' professional training and skills to facilitate inclusive education within the context of visual impairment. Participants were conversant with inclusive education from both the practical and academic points of view. Their definition needed some clarity at times as some were not clear what it stands for in the context of visual impairment. All participants were able to offer somewhat useful information on what it means, and how the South African education system paraphrases the concept.

Kate: "I am sure that inclusive education defines the exclusive system of education responsible for catering to the needs and wants of learners with certain learning challenges and disabilities."

Sthabana: "My knowledge of inclusive education personally comes from the institutions of state built to cater for learners with unique conditions. At times these learners are normal, but they struggle to perform certain activities without assistance."

Makuya: "it is hard to define inclusive education, but suffice it to say, this is a system of education designed for a group of learners with a critical condition. Of course, these conditions are sometimes mild, while others are shown to be severe. And they need special care to perform numerous activities in the school setting as well as in the normal environment."

The majority of participants succinctly explained inclusive education within these parameters of a physically challenged person who needs special support to achieve educational goals. The Education Department came up with this form of system to cater for these learners differently from the rest of the learners. It was clear from the definition that only specialised teachers should be given this exclusive responsibility to support these learners' learning and achieving their full potential. The fact that people with general skills care for this group has been known to be frustrated, but the question of isolation remains the biggest challenge. In a recent curriculum revision, the Department of Basic Education took a global view about what should be the norm when treating learners who are physically challenged. This finding of the study coincides with the works of $[8,9]$ who hold the view that inclusive education is an effort made towards building a learning environment that promotes full, personal, academic and professional development of all learners, regardless of their disability. Ref. [9] also adds that it is sequel to recommendations to all countries of the world to implement inclusive education as a cost-effective alternative to educating children with disabilities. This study investigated the experiences of teachers who cater for the needs of visually impaired learners in the general education context. This was the main purpose of sharing their experiences. One of the participants, who had a single year of teaching experience in the field of inclusive education, teaching visually impaired learners, had this to say about professional training and skills:

Pearl: "I hold a BA degree in Psychology and a $P G C E$, making me a highly qualified teacher to teach learners with this condition. Even though my skills are sometimes called into question, I am learning every day to offer the care needed in this sector. Attending workshops has been helpful to improve my knowledge and expertise. I wish I could enrol in a short course specialising in literacy and numeracy for learners with visual impairment."

Takalani: "It has been a dream come true to work in this environment. As for my qualification, I hold a four-year Bachelor of Education degree (B.Ed) to teach these learners with pride. There have been many challenges to face for the last two years working with learners with visual impairment."

Most of the teachers are professionally qualified in their pedagogical content knowledge. This finding agrees with the work of [2] who opines that visual impairment is only a condition, and all learners deserve quality education from qualified teachers in order to access opportunities for 
lifelong learning, equal work opportunities, and participation in society. However, the finding further shows that there was a serious discrepancy that kept on raising a red flag about all of them. Participants were bragging about how well qualified they were to work in the selected school, but they lacked the specialised training necessary to support visually impaired learners. The fact that most of them had done Psychology and Education was not enough to elevate their status to teach a fragile group of learners with special needs. This finding corroborates the works of $[18,36]$ who hold the view that issues revolving around specialization affect the training of visually impaired learners. Meanwhile, from the interviews, two in the group reminded the interviewee about the module called Special Education offered in Education for all students, and this was the only relevant module in the B.Ed programme:

Lunduwva: "Let me remind you, sir, that at the University, we did a module called Special Education, and if I remember well, it was a core module. In this module, we were told that the education system in South Africa is advocating inclusive education. This by definition means that in our schools we are required to teach learners who are challenged in the mainstream."

Shabana: "Indeed, we were prepared in advance to work in the public schools with learners with different abilities. The reality is that government is working hard to eliminate private centres where learners with physical and psychological challenges are learning alone or isolated from the rest."

It was difficult to tell whether participants were capable of working with learners with special conditions. Their professional training was impeccable, but serious questions were raised about their skills. As was to be expected, participants believed they had the minimum content knowledge required to teach in the inclusive classroom. Given that the environment demands specialised skill, it was not clear how they were able to compensate for this critical deficiency in their teaching. In brief, teachers were unable to state with certainty what skill sets they had, and this was an unfortunate state of affairs facing the schools. Report of teachers indicated that teachers who participated in this study were set to do anything to remain employed by the Department. In another set of responses, skills were considered to be intriguing. Some of the reports from the participants in this regard are presented as below:

Shabana: "I have considered myself a novice teacher, and my experience is on the right track because I attend workshops where I am learning every time I get an opportunity. Also my SMT is so supportive and always encouraging me to learn as much as possible, because they don't have enough courageous teachers to work with visually impaired learners in this school. The reality is that I have to rely on the School for the

\begin{abstract}
Blind and other psychologists, and everybody else you can bring in to assist that has more knowledge and experience than you."
\end{abstract}

Lunduwva: "it's a new day every day. In this profession, you feel like you're starting fresh, and you never know if your intervention has made any difference or not. It is complex, and one needs a lot of patience and resilience when working with visually impaired learners. You just feel like you should know that, but it's something new."

Lunduwva found she was responsible for teaching others to help her. She believes all members of her team are making a difference. Helping every member of her team empowers them to work as a unit to educate the students with visual impairment. This participant recognised the needs of students in FP, which always vary greatly from those in Senior Primary schools (Intermediate Phase), but agreed that with time the level of competence improves. Working with visually impaired learners for one and a half years is considered nothing in relation to the magnitude of the work in their class. One of the strategies is to involve parents of these learners in reinforcing skills.

Pearl: "As a teacher in this sector, you carry a lot of responsibility, but you also need to empower parents of these learners with information and relevant strategies. I call these supports, and these are tools or cues responsible for helping paraprofessionals, and at times this might even help their peers to understand how to assist and work with visual impairment."

The mainstream Curriculum and Assessment Policy Statement (DBE 2011), that qualified general teachers lack the exposure to special needs teaching before teaching in this environment, coupled with a lack of proper training, does not ensure the inclusive education that is required by the South African Constitution. Teachers in this study claimed that through their experience they had learned some skills in teaching visually impaired learners. They have collaborated with experienced teachers and therapists who offered support for free. The Braille Unit supported new appointees in creating resources. This finding of the study agrees with the works of $[18,36]$ who call for the need for specialization when dealing with visually impaired learners. Furthermore, the finding from theme 1 contradicts the views of $[1,4]$, who found that novice teachers are unable to provide professional academic training and skills for learners with visual impairment in an inclusive environment. Meanwhile, [48] claim that collaboration between teachers and other professionals not only decrease the challenges the teachers face, but ensure that the learner is supported. Additionally, following the finding from theme 1 , it was evident from the various views of participants that a lot of changes seemed to have occurred in schools, and some few lucky learners are blessed with highly competent teachers. However, sequel to the work of [14], all teachers need to know the important 
concepts, skills and facts of visual impairment curriculum to teach with confidence. Ref. [36] opine that teachers who have an intrinsic love for teaching in an inclusive environment develop a close relationship with learners with learning barriers, as they need support, undivided attention and patience. Meanwhile, the most significant point consistent with the findings is made by Johnson-Jones[24], who stresses that all teachers should know how to teach reading and numeracy to learners with visual impairment.

\section{Theme 2: Teachers' experience of academic and extracurricular activities}

The second theme to emerge in this study focused on teacher's priorities that keep them motivated between academic and extracurricular activities. It was clear from participants who teach learners with visual impairment that they prioritise instructions in the academic curriculum over non-curriculum areas. Teachers are usually forced by their tight schedules to lean towards academic instruction, inadvertently neglecting important extracurricular activities. For participants in this study, the rationale was evident when they stressed that academic activities always supersede everything they are about in these schools. Notwithstanding the value of extracurricular activities like playing, or debating, their role is firm in ensuring that teaching and learning remains a high priority.

Shabana: "I am sure that what makes parents excited is to see their kids returning home with practical evidence that something of value is taking place at school. Seeing them writing, pronouncing words, using strategies for learning to navigate in the house puts a smile on their faces."

\begin{abstract}
Kate: "My sole responsibility is to focus on teaching compensatory skills, and where possible assistive technology skills. These are the most critical areas that form the basic foundation of the programme for visually impaired learners. Everything we do is built on this firm foundation. Let me hasten to say that we do combine extracurricular activities with these skills, but we believe that schools should hire relevant people to keep these learners active and always sports savvy.
\end{abstract}

According to Guerette[49], compensatory skills focus on concept development, spatial understanding, communication needs, speaking and listening, study, and organisation. These participants championed the development of these important skills for learners, and pointed out that the difficulty they encounter is when these learners are not making enough progress in these areas. Indeed, these skills are part of the academic curriculum vital for learners to master and understand for assessment purposes. Makuya and Lunduwva are experienced in teaching visually impaired learners, and acknowledge the need for extracurricular activities as part of the curriculum. Makuya: "Only focusing on the professional side of the curriculum weakens our intervention in many ways. Learners with visual impairment have a short concentration span, and giving them more work frustrates them significantly. When you ask them to play and engage in creative activities, they lighten up, and you can see their spirits come alive."

Lunduwva: "My main focus is the academic side of the curriculum, in particular, conceptual development, speaking, and listening. Well, I am one of those guilty parties when it comes to neglecting extracurricular activities."

The development of compensatory skills dominated the whole discussion concerning priorities, and in this regard, these teachers of visually impaired learners agreed to expand their scope. In terms of the scope, they were referring to moving away from a one-dimensional perspective of only developing compensatory skills, and allowing non-academic activities to be part of the daily curriculum. The issue for further discussion was the support in terms of manpower and within the school set-up. Some teachers take the inclusive education idea as a joke aimed at those teachers with less important subjects who need sympathy. It was heart breaking to hear these professionals complaining about the lack of awareness from the public officials, and the bad attitude towards inclusive education. The lack of important teaching resources confirmed their suspicion, and indicated the real frustration that Pearl was trying to highlight in her viewpoint:

Pearl: "For your information, learners with visual challenges need more resources such as specialised books and other teaching material. These resources are meant to cover extracurricular activities for this group. As you can imagine, their movement is limited, and it needs physical resources to assist them to play and develop full mobility. After all, they are kids."

Our experience is curtailed by the school environment. Even the SMT has very little support, except in following DBE guidelines. The officials promise to provide resources, but as you can see, 'nothing gets delivered' said Pearl.

The finding of theme 2 following the reports of participants suggests that teachers of visually impaired learners were mainly paying attention to academic development, neglecting the most critical component of learning for FP learners, which is extracurricular. Meanwhile following the finding of the work of [36], visually impaired learners tend to rely on their senses of touch, hearing, smell, taste, movement and residual vision to gather information from their learning environments. Hence, the need to engage them in extracurricular activities remains necessary. For instance, playing games using technology has proven to significantly improve the concentration, passion and problem-solving abilities of 
these learners. This finding agrees with the works of $[18,36,37,38]$ who hold the view that some barriers such as technology hamper the learning abilities of visually impaired learners. Moreover, in instances where extracurricular activity is neglected, academic intervention alone might not succeed. The impact of compensatory skills is proposed by Guerette[49], who argues that teachers of visually impaired learners should focus their attention on conceptual development, spatial understanding, speaking and listening, just to name a few activities. This study consistently found that most teachers are paying special attention to these important aspects of the academic programme, and neglecting others.

\section{Theme 3: Teaching beyond the curriculum}

The third theme prompted the issue of what teachers offer beyond the curriculum. It emerged very clearly that learners with visual impairment need highly dedicated, responsible and visionary teachers. These are professionals who teach beyond the traditional curriculum. Many issues that were identified in this section were considered, and some that were not articulated well were left out of this study. Participants highlighted four important issues that changed their outlook and motivated them to work even harder to assist learners with visual impairment. Pearl was focused on mobility and orientation skills while Takalani saw independent living skills as fundamental in working with these learners:

Pearl: "Let me educate you on this issue, My role, beyond teaching academically, is to help them with their positions in relation to their environment, focusing on building a mind map about how things in their environment are related physically and spiritually. I also like to deal with mobility skills where I specifically help them with physical identification of the road using a cane during travel.".

Takalani: "After every formal academic teaching, my interest has always been based on the everyday activities that define their day. In this case, personal hygiene, dressing, managing finances, and playing linked to daily activities and interactions. As you can imagine, there are various activities planned for them to do every day related to sending them to shop, and asking them to count money and bring back the correct change. Since these are kids, you take full advantage and cooperate as much as possible.".

These two participants were happy to develop these skills important to visually impaired learners, but over and above these, one teacher raised an important issue of self-appraisal and self-actualisation. The researchers never expected this to be the issue, but the way it was justified gave hope about the calibre of teachers we have in our schools. Learners are taught about their rights and responsibilities in a broad scheme of things in South
Africa.

Shabana: "I always make an effort to encourage them to know their rights as people living with visual impairment, and that their decisions should always depend on their natural abilities and strengths. They must know that they have the right to make choices that suit their needs and wants, know how to solve problems independently, set their goals, and achieve them."

This finding from the study suggests that, it is important to empower visually impaired learners to become independent and successful. This finding corroborates the work of $[14,15]$ who hold the view that visually impaired learners are to be empowered, however, teachers are to have basic understanding of their unique learning needs in order for such to be achieved. In other words, it is significant for teachers of visually impaired learners to know their goals, and work towards achieving them. Moreover, such is expected to enhance their professional and personal development. Also, the findings of theme 3 underscored the importance of academic competence, but the question of helping these learners to cope with fundamentals of life kept on surfacing. The results pointed to self-appraisal and self-actualisation as important measures to be developed. This finding is supported by Downing[50], who argues that learners with visual impairment must be assisted to be independent and successful in their own right. Suffice to state that a targeted programme is expected to be provided for teachers of the visually impaired to help build their confidence and self-love.

\section{Conclusions}

The main purpose of this study was to examine the perceptions and experiences of teachers of learners with visual impairment in the inclusive environment, mainly focusing on teachers' professional training and skills, and experience in prioritising and teaching beyond the curriculum. The study findings showed that the main prerogative of inclusive education, and, in particular, visual impairment education, is to serve the needs and aspirations of all learners, and elevate the learners to reach their maximum potential against all odds. In addition, the findings of the study showed that novice qualified teachers have good understanding of their responsibility in rendering learning support, and the vital importance of communicating their support in clear language understood by everyone. Additionally, the finding of the study showed that the importance of paying special attention to teachers' priorities to better understand whether their experiences contribute to learners' holistic development. In essence, teaching covers many facets of the curriculum, including pedagogy, extra- curricular activities, and social or lifelong learning. Furthermore, the study finding also showed that 
there is need for the designing of a suitable programme for teachers of visually impaired learners in order to enhance and boost their confidence and self-love when dealing with the identified learners, so as to ensure success. In the light of the findings, the study recommends that novice teachers should be supported theoretically, technologically, and in resource capacity. Their work is ten times more difficult than the work of the ordinary teachers. Putting their lives up against the wall in the name of patriotism should be backed by tangible support and resourcing. Technology is changing every day, and there was very little information to be learned about improving teachers' technical skills to promote literacy and numeracy. Also, a special programme targeted at helping teachers of visually impaired learners should be organised periodically in order to empower them to deliver the job as desired. This can be organised by the government through the specialists in the field.

Additionally, because the study focused on specific teachers using qualitative approach, further studies which can include more teachers from various special schools, as well as the use of quantitative method is suggested. This is envisaged to aid generalization of results.

\section{Acknowledgments}

The authors are grateful to the University of KwaZulu-Natal and the selected institution where data was collected for all the support received.

\section{REFERENCES}

[1] B. Mwakyeja. Teaching students with visual impairment in inclusive classrooms: A case study of one secondary school in Tanzania. Unpublished master's thesis, University of Oslo, 2013.

[2] P. Du Plessis. Legislation and policies: Progress towards the right to inclusive education, De Jure Vol.46, No.1, 76-92.

[3] N. Morelle. Challenges experienced by learners with visual impairment in two mainstream primary schools in Klerksdorp, Dr. Kenneth Kaunda District. Pretoria: M.Ed dissertation, University of South Africa, Pretoria, 2016.

[4] M.A. Kao, P.J. Mzimela. They are visually impaired, not blind ... teach them!: Grade $\mathrm{R}$ in-service teachers' knowledge of teaching pre-reading skills to visually impaired learners'. South African Journal of Childhood Education, Vol.9, No.1, a651. https://doi.org/ 10.4102/sajce.v9i1.651

[5] Department of Basic Education. Guidelines for full-service/inclusive schools. Special needs education: Building an inclusive education and training system. Education White Paper 6. DBE, Pretoria, 2010.

[6] Department of Basic Education. Guidelines for responding to learner diversity in the classroom through curriculum and assessment policy statements. DBE, Pretoria, 2011.

[7] DfE. Special education needs and disability code of practice: 0 to 25 years. Statutory guidance for organisations which work with and support children and young people who have special educational needs or disabilities. Retrieved from: https://assets.publishing.service.gov.uk/, 2015

[8] Department of Education. Special needs education: Building an inclusive education and training system. Education White Paper 6, DoE, Pretoria, 2001.

[9] UNESCO. World Education Forum 2015. Online available from:

http://en.unesco.org/world-educationforum-2015/incheon-d eclaration.

[10] E. Gatbonton. Looking beyond teachers' classroom behaviour: Novice and experienced ESL teachers' pedagogical knowledge. Language Teaching Research, Vol.12, No.2, 161-182.

[11] W.J. Fraser, M.O. Muguvhe. Teaching life sciences to blind and visually impaired learners. Journal of Biological Education, Vol.42, No.2, 84-89.

[12] UNESCO. The Salamanca Statement and Framework for Action on Special Needs Education Adopted by the World Conference on Special Needs Education: Access and Quality, Salamanca, Spain, 7-10 June, 1994. Paris: UNESCO/Madrid: Ministry of Education, 1994

[13] M.S. Felman. Managing for inclusion: Balancing control and participation. International Public Management -Journal, Vol.3, 149-167.

[14] M. McLinden, J. Ravenscroft, G. Douglas, R. Hewett, R. Cobb. The significance of specialist teachers of learners with visual impairments as agents of change: Examining personal preparation in the United Kingdom through a biological systems theory. Journal of Visual Impairment \& Blindness, Vol.111, No.6, 569-584. https://doi.org/10.1177/0145482 X1711100607

[15] D. Fast. Including children with visual impairments in the early childhood classroom. OH: The Ohio State University Press, Columbus, 2018.

[16] Media Access Australia. Sociability: Social media for people with a disability. Media Access Australia, Sydney, 2016.

[17] W. Sapp, P. Hatlen. The expanded core curriculum: Where we have been, where we are going, and how we can get there. Journal of Visual Impairment and Blindness, Vol.104, 338-346.

[18] J.A. Bardin, S. Lewis. A survey of the academic engagement of students with visual impairment in general education classes. Journal of Visual Impairment \& Blindness, Vol.102, No.8, 472-483.

[19] M. Wagner, J. Blackorby, K. Hebbeler. Beyond the report card: The multiple dimensions of secondary school performance of students with disabilities. A report from the National Longitudinal Study of Special Education Students. Menlo Park, CA: SRI International. (ERIC Document Reproduction Service No. ED 365 088), 1993.

[20] J. Ravenscroft. A discussion on what is a qualified teacher of pupils with visual impairment. British Journal of Visual Impairment, Vol.33, 161-166. 
[21] K. Lamichhane. Teaching students with visual impairment in an inclusive educational setting: A case from Nepal, International Journal of Inclusive Education, Vol.21, No.1, 1-13. doi: $10.1080 / 13603116.2016 .1184323$

[22] E.K. Gyimah, D. Sugden, S. Pearson. Inclusion of children with special educational needs in mainstream schools in Ghana: Influence of teachers' and children's characteristics. International Journal of Inclusive Education, Vol.13, No.8, 787-804.

[23] M.A. Ocloo, M. Subbey. Perception of basic education schoolteachers towards inclusive education in the Hohoe District of Ghana. International Journal of Inclusive Education, Vol.12, 639-650. doi:10.1080/13603110802377 680

[24] K.J. Johnson-Jones. Educating students with visual impairment in the general education setting. $\mathrm{PhD}$ thesis, The University of Southern Mississippi, Hattiesburg, Mississippi Online available from: https://aquila.usm.edu/dissertations/ 1337,2017

[25] American Foundation for the Blind (AFB). Expanding possibilities for people with vision loss. Journal of Visual Impairment \& Blindness, Vol.109, No.6, 1-15.

[26] S. Hartlen. The cultural impact of short-term study abroad programs (Order No. 1501357). Online available from ProQuest Dissertations \& Theses A\&I; ProQuest Dissertations \& Theses Global.

[27] C.H. Yang, E. Rusli. Using debate as a pedagogical tool in enhancing pre-service teacher's learning and critical thinking. Journal of International Education Research, Vol.8, No.2, 135-144.

[28] Y. Feng. University of Nottingham Ningbo China and Xi'an Jiaotong-Liverpool University: Gbalization of higher education in China. High Educ., Vol.65, 471-485.

[29] F.L.M. Lee, A.S. Yeung, D. Tracey, K. Barker. Inclusion of children with special needs in early childhood education: What teacher characteristics matter. Topics in Early Childhood Special Education, Vol.35, No.2, 79-88

[30] B.A. Lee. Students with disabilities: Opportunities and challenges for colleges and universities. Change: The Magazine of Higher Learning, Vol.46, No.1, 40-45

[31] T. Tinklin, J. Hall. Getting around obstacles: Disabled students' experiences in higher education in Scotland. Studies in Higher Education, Vol.24, 183-194.

[32] G. Batsche. Colorado state special education director meetings: CDE materials from the RtI implementation team (2006-2007). Alexandria, VA: National Association of State Directors of Special Education, 2006.

[33] L. Hopkins. The path of least resistance: A voice-relational analysis of disabled students' experiences of discrimination in English universities. International Journal of Inclusive
Education, Vol.15, No.7, 711-727.

[34] P. Rowlett. The unplanned impact of mathematics. Nature, Vol.475, 166-169.

[35] O. Konur. Teaching disabled students in higher education. Teaching in Higher Education, Vol.11, No3, 351-363

[36] S.L. Zwane, M.M. Malale. Investigating barriers teachers face in the implementation of inclusive education in high schools in the Gege branch. Swaziland. African Journal of Disability, Vol.7, No.0, 1-12.

[37] C. Gray. Inclusion, impact and need: Young children with a visual impairment. Child Care in Practice, Vol.11, No.2, 179-190.

[38] C. Gray. Support for children with visual impairment in Northern Ireland: The role of the rehabilitation worker. British Journal of Visual Impairment, Vol.26, No3, 239-254.

[39] R.K. Yin. Case study research: Design and methods. CA: Sage, Los Angeles, 2014.

[40] R.K. Yin. Qualitative research from start to finish. The Guilford Press, Los Angeles, 2011.

[41] K. Maree. First steps in research. Van Schaik, Pretoria, 2009.

[42] E. Babbie. The basics of social research ( $3^{\text {rd }}$ ed.). Belmont, CA: Thomson Wadsworth, 2005.

[43] C. Bertram, I. Christiansen. Understanding research: An introduction to reading research. Van Schaik, Pretoria, 2014.

[44] D.M. Oppenheimer, T. Meyvis, N. Davidenko. Instructional manipulation checks: Detecting satisficing to increase statistical power. Journal of Experimental Social Psychology, Vol.45, No.4, 867-872.

[45] W.L. Neuman. Social Research Methods: Qualitative and Quantitative Approaches. 7th Edition, Pearson, Boston, 2011.

[46] M.T. Blanche, K. Durrheim, D. Painter, D. (Eds.). Research in practice: Applied methods for the social sciences. Juta, Cape Town, 2006.

[47] J.A. Maxwell. Qualitative research design: An interactive approach $\left(3^{\text {rd }}\right.$ ed.). SAGE, Thousand Oaks CA, 2013.

[48] M. Lehohla, D. Hlalele. Inclusive classrooms: An ecosystemic perspective. Journal of Human Ecology, Vol.37, No.3, 189-201.

[49] A.R. Guerette. Compensatory access. In C.B. Allman \& S. Lewis (Eds.), ECC essentials: Teaching the expanded core curriculum to students with visual impairment (pp. 61-108). AFB Press, New York, NY, 2014.

[50] J.E. Downing. Academic instruction for students with moderate and severe intellectual disabilities in inclusive classrooms. Corwin, Thousand Oaks, CA, 2010. 